\section{Zaklina Spalevic ${ }^{1}$}

Sinergija University, Faculty of Tourism and Hospitality, Bjeljina, BiH

\section{Milos Ilic ${ }^{2}$}

University of Pristina,

Faculty of Technical Science Kosovska Mitrovica

\section{Vladimir Savija ${ }^{3}$}

Public institution Gymnasium Filip Višnjić, Bijeljina
SCIENTIFIC REVIEW ARTICLE doi:10.5937/ekonomika1804091S

Received: October, 29, 2018 Accepted: November, 25, 2018

\title{
THE USE OF DRONES IN AGRICULTURE - ICT POLICY, LEGAL AND ECONOMICAL ASPECTS
}

\begin{abstract}
The rapid development of information and communication technologies from the standpoint of hardware and software resources has led to their increasing application in various areas of everyday life and work. One of the novelties of the hardware industry are the drones. The set of services that drones offer have enabled their use in many areas. One of the currently popular areas for usage of drones is agriculture. Agricultural fields in which a drone can be used depends largely on its equipment, primarily set of sensors and/or high resolution cameras. This paper gives an overview of use cases in agriculture where drones are suitable for use. Furthermore, advantages and limitations of using such aircraft are given. From different economical and legal aspects the use od drones is described. The use of drones in agriculture can greatly contribute to the development of precise farming, reducing production costs and the production of healthier food.
\end{abstract}

Key words: Dones, agriculture, DJI Phantom, legal issues, economical benefits JEL classification: $032,033, Q 16$

\section{ИНФОРМАТИЧКА, ПРАВНА И ЕКОНОМСКА КАРАКТЕРИЗАЦИЈА УПОТРЕБЕ ДРОНОВА У ПОЉОПРИВРЕДИ}

\begin{abstract}
Апстракт
Убрзан развој информационо комуникационих технологија са становишта хардверских и софтверских ресурса довео је до њихове све веће примене y различитим областима свакодневног живота и рада ьуди. Један од новитета хардверске индустрије свакако су и мале беспилотне летилице
\end{abstract}

\footnotetext{
${ }^{1}$ zspalevic@sinergija.edu.ba

${ }^{2}$ milos.ilic@pr.ac.rs

${ }^{3}$ ss54@skolers.org
} 
популарно назване дронови. Скуп сервиса које дронови нуде омогућио је њихову употребу у многим областима. Једна од актуелних области примене дронова је пољопривреда. Делатности у којима дронови могу бити заступљени у области пољопривреде зависе у многоме и од опремељености самог дрона различитим сетом сензора и/или камерама високе резолуције. У раду је дат преглед примене дронова у пољопривреди са становишта области погодних за юихову употребу. Такође су обрађене предности и ограничења употребе оваквих летилица. Предности и недостаци су описани са различитих економсих и правних аспеката. Њихова употреба у многоме може допринети развоју преичизе пољопривреде, смањењу трошкова производње и производюи здравије хране.

Кључне речи: Дронови, пољопривреда, ДЈИ Пхантом, правни аспекти, економске предности

\section{Introduction}

The agricultural development strategy in order to produce quality agricultural products in recent years is developing in the direction of the so-called controlled production and precise agriculture. There are different definitions of precision agriculture. The global concept on which precision agriculture is based is the use of information and communication technologies for the collection and processing of data obtained from various sources. The obtained data are used for the purpose of making a better approach to the cultivation of cultivated plants (Srinivasan, 2006). Under this domain, we can categorized systems for collecting data from the field, field mapping, decision making as well as automation of certain agricultural production processes (Robertson at.el. 2007). A certain number of research shows that automation of agricultural production is still at an early stage, mainly due to the difficult conditions in which automated machines operate: inaccessible and uneven terrain, different types of soil, as well as changes in weather conditions (variation of temperature, precipitation, humidity, dust, etc.).

The key techniques on which precision agriculture is based are remote sensing techniques. One of the most used techniques in novel time is to capture production areas from the air (Barrientos at.e., 2011). Remote control platforms used to collect the necessary information on the basis of a series of land-based photos can include: satellites, balloons, planes, and small drones. The use of satellites and planes is expensive and time-consuming, so the recording process can not be repeated frequently. Drones on the other hand offer simpler working mechanisms, good fitting sensors (optical, infrared, sensors for radio detection and ranking, ...) and different types of cameras (RGB, NIR, RE, MultiSpec, ThermoMap), the possibility of frequent repetition of the flight above the production area, and all that at a significantly lower price (Zhang \& Kovacs, 2012). Drones are small in size, easy to transport and assemble, they provide instant response to the project requirements as well as quick engagement on the ground. Some of the applications applied in agriculture, based on the processing of images obtained using drones, include: application for monitoring and mapping the condition of the soil, classification of plants on production areas, monitoring the occurrence of diseases and 
pests, stress detection in plants caused by excess water, detection of water deficiency in soil, analysis of plant leaflets on pesticide content, assessment of the state of biomass of plants, as well as monitoring of the number of weed plants on production areas (Lan et.al, 2009).

The aim of this study is to analyze the current state of drone use in agriculture, as well as the types of drones that are commonly in use. Such as the use of large aircraft, the use of drones is governed by the rules laid down by the Directorate of Civil Aviation, both in Serbia and abroad. The paper provides legal frameworks for the use of drones on the territory of Republic Serbia as well as their comparison with the legal regulations abroad. Apart from legal aspects, the use of drones was also analyzed from an economic point of view.

\section{Types of drones in commercial use}

The scope of drones application in precision agriculture covers different areas and purposes. Selecting a specific drone, and the equipment will largely depend on the drone's purpose. Drones that can currently be purchased on the market and therefore used in the field of precise agriculture can be divided into two categories: fixed-wing drones and so-called quadcopters (or multi-rotor drones) (Nixon, 2018). Both categories contain a larger number of models from different manufacturers.

The category of drones with fixed wings is based on three models: Sensefly eBee, PrecisionHawk Lancaster and Trimble. Sensefly eBee is an economical and convenient system for extremely low-dimensional photogrammetry. It stands out with easy handling and launch by hand with a steep take-off and the possibility of lowering in small spaces. In the standard version these drones are equipped with an infrared camera, but can be subsequently equipped with plug-ins that as a result create a 3D thermal map of the space (Nixon, 2018). Also, using eMonition software, they can connect to computers and tablet devices in order to simulate the flight and determine the flight path before before takeoff drone. In addition to the simulation, this software also allows the subsequent change of the originally set path of the drone while it is in the air. It is also compatible with the Google Earth service. The maximum coverage range for a single flight duration varies from $2.2 \mathrm{~km}^{2}$ to $40 \mathrm{~km}^{2}$ depending on flight height and weight of equipment. The proven maximum flight time in practice is 59 minutes. Resolution on the ground is up to $1 \mathrm{~cm}$ per pixel (Livona, 2017).

The second model in category with fixed wings is PrecisionHawk Lancaster. This drone is completely autonomous and easy to use. Like the previous model, it also launches out from hand. After lasing he starts to collect data from a predetermined flight path. After the flight tour, the drone starts mechanism for automatic landing (Precision Hawk, 2014). It is equipped with a large number of sensors that can be changed in the field without additional configuration of the aircraft itself. Due to a weight of $2.4 \mathrm{~kg}$ without additional equipment, which is $1.3 \mathrm{~kg}$ more than the weight of the previous model, the maximum flight time of this model is about 45 minutes. The maximum average coverage for one flight is about 300 hectares at a height of 100 meters. The maximum speed of this model is $79 \mathrm{~km} / \mathrm{h}$.

Trimble Dron is the third model in the category of drons with fixed wings. This drone is more powerful and faster than other models, which allows it to capture a larger 
surface in the same time period (Trimble, 2017). For example, the maximum flight duration of the UX5 Trimble model is about 50 minutes, at a speed of $80 \mathrm{~km} / \mathrm{h}$. The body of the aircraft is made of graphite fibers, which gives it high resistance and stability, and a reliable flight at high wind speeds (up to $18 \mathrm{~m} / \mathrm{s}$ ) or even stronger rain, when other systems have to be grounded. It has its own software package for tracking and recording terrain as well as the subsequent processing of high quality photos in the RGB and NIR variants. All three models, in addition to connecting to base stations, can also be connected with smart devices within agricultural machines in order to get these machines from the latest data from the field.

The category of quadcopter drones includes a large number of different models. For application in agriculture, three groups of quadcopter models can be distinguished: AGCO Solo, senseFly eXom and DJI multi-rotors drones (Nixon, 2018). Each group contains a large number of different performance models. Each model, as its name suggests itself, is equipped with four engines each of which is powered by one propeller. This mobility solution ensures high accuracy of movement, reduces the required surface for take-off and landing, but at the same time consumes more energy. Also, these models have an option that allows the device to return to the base station. The specific purpose of this functionality consists in the fact that the airplane independently takes care of the required amount of energy to return to the base station, which reduces the possibility of falling aircraft due to power failure (Solo, 2017).

The first of the AGCO Solo models has the ability to be remotely control from the ground as well as the autonomous flight according to the predetermined route. The flight duration of this model with the basic set of cameras is about 20 minutes, while the maximum speed is about $88 \mathrm{~km} / \mathrm{h}$. It is equipped with two specialized cameras for mapping the earth's surface. First camera is the GoPro Hero 4 for the RGB spectrum, and the second is NIR GoPro camera for the infrared spectrum. It is suitable for creating orthomosics as well as creating the NDVI (Normal Difference Vegetation Index) map of the state of the plants. The SenseFly's eXom model was created for field inspection and mapping in close proximity. It offers recording of various recordings including HD images, ultra HD images, and thermal images of the surface. All three cameras are located in one moving head. The entire recording head can rotate to $270^{\circ}$, while each camera can be rotated independently in the head in the range of $50^{\circ}$ to $100^{\circ}$. In addition to the camera equipment, it is equipped with a set of motion sensing sensors as well as a set of ultrasonic sensors, which enables the operator great precision when managing the aircraft (Inside Unmanned System, 2017). This type of aircraft equipment offers the ability to shoot from proximity to achieve a resolution of less than one millimeter. Weight of the model with complete equipment is $1.8 \mathrm{~kg}$. The maximum flight length is up to 22 minutes, while the maximum speed is $25.2 \mathrm{~km} / \mathrm{h}$. The aircraft can withstand wind blows up to $8 \mathrm{~m} / \mathrm{s}$.

The DJI multi-rotor group of drones contains a larger number of models. The characteristics of these models when it comes to their application in agriculture vary from drones for beginners to professional drones. For example, one of the newer models called DJI Phantom 4 Pro is equipped with a one-inch 20MP sensor that delivers a dynamic range of approximately 12 blends. Video is $4 \mathrm{~K}$, but with $\mathrm{H} .265 \mathrm{codec}$, the whole process is faster and easier: 4096 × 2160 with $30 \mathrm{fps}$ and 3840 x 2160 with $30 \mathrm{fps}$, at 100Mbps. Of particular relevance is the new mechanical shutter, which eliminates the deformation 
of the image when shooting moving targets (so-called rolling shutter effect) (DJI, 2017). As far as the lens is concerned, its focal length is $24 \mathrm{~mm}$, with a viewing angle of $84^{\circ}$ while the aperture value is $\mathrm{f} / 2.8-11$. The aircraft is equipped with three sets of visual systems that are tasked to, in a three-dimensional space, map and guide the ramps to obstacles in front, behind and below the aircraft to avoid collisions (to detect objects that are located distant up to $30 \mathrm{~m}$ from the drone). In addition to these three sets of systems, on both sides of the Phantom 4 Pro there are infrared obstacle detection systems that can spot foreign bodies at a distance of 0.2 to $7 \mathrm{~m}$ from the drone. In addition to the standard return functionality to the base station, this model also includes the so-called Landing Protection option which ensures that when landing the aircraft does not land on uneven terrain or in water. This model can reach a maximum speed of $72 \mathrm{~km} / \mathrm{h}$ in the so-called Sport mode, the uphill speed is $6 \mathrm{~m} / \mathrm{s}$ and a lowering speed of $4 \mathrm{~m} / \mathrm{s}$. The maximum flight length is 30 minutes (Pcfoto, 2016). The remote control, unlike any other model that requires the use of one of the smart devices (phone, tablet) equipped with its own screen, which additionally features built-in GPS, compass, HDMI port and microSD card slot. The remote can communicate with the aircraft up to a distance of $7 \mathrm{~km}$.

The both categories of drones (with fixed wings and quadcopters) are successfully applied in different areas of agriculture depending on the specific needs of users. The method of using drones for the purpose of collecting and processing data from the field can be divided into five phases (Parrot, 2017). In the first stage, it is necessary to select the appropriate cameras and sensors to which the dron will be equipped in order to collect the necessary data, in accordance with the possibilities of the drone itself. After preparing and checking the drone functionality, it is necessary to carry out the flight and collect the necessary data. On the basis of the collected parameters, initial terrain maps, orthomozoic, or NDVI maps of planted crops can be created. The second phase is based on analysis of images and data obtained after the completed flight. Basic processing and data overview in most cases can be done with the built-in software on the remote control of the aircraft. More detailed information is obtained by processing the received images to some of the specialized software on a separate computer. Different methods are used to process the data thus obtained, in addition to processing images from the same extracts meta data. In order to check the accuracy of data in the third phase on the field, control points can be selected to compare the actual state of the production area with the state obtained by processing the collected data (Parrot, 2017). In the fourth phase, an assessment of the state of the recorded area or its individual parts is made. For example, in this phase, an assessment of the damage done to crops under the influence of various diseases and pests, as well as climatic factors, is carried out. At this stage, an assessment of additional irrigation or assessment of the occurrence of adverse effects of the presence of too much water on the surface it also can be made, which causes the need for drainage. On the basis of all implemented assessments in the fifth phase, a plan of future activities which should be applied over the observed production area (saving of production area or some specific parts, installation of drainage systems, activation of irrigation systems, protection against diseases and pests, ...) can be implemented. Such a plan of activities can be activated if we work with automated machines that will transferred geo-data to a set of instructions for the given machine. In this way precise processing of the concrete surface can be done. For example, it can be determined in advance which part of the area will receive as much nutrients, more or less water, as well as chemical treatment for protection against diseases and pests. 
By comparing the models from both categories, it can be seen that fixed-wing drones can achieve longer flight time and can cover a larger surface over a period of one flight. At the same time, unlike the quadcopter, they can pick up a smaller load that limits them in terms of camcorder equipping. When it is necessary to create more precise photographs, to do a more detailed inspection of the terrain and when is necessary to take-off and landing on a small surface, quadcopters are definitely a better choice.

\section{The use of drones in agriculture}

During many researches, it is confirmed that drones have been widely used in agriculture. One of the basic purposes of the drones is to monitor the current health condition of crops on production areas. In order to solve this task, the drones should be equipped with cameras for recording different wavelengths of the solar spectrum. In this way, by processing recorded photographs, the state of agricultural crops can be estimated using the already mentioned NDVI maps (Oljaca et.al., 2016). These maps are based on the NDVI index, which takes the value of the difference between the intensity of the reflected wavelength of light from two different frequencies. The first frequency is VIS (visible part of the spectrum, 400-700 nm), while the second NIR (infrared part of the spectrum, 700-1300 nm). Applied to reflection by capturing vegetation, chlorophyll of a healthy plant absorbs most of the visible part of the spectrum of light that is used in the photosynthesis process. On the other hand, healthy plants reflect a large part of the infrared portion of the spectrum. The space covered by the vegetation of weaker physiological state, as well as the area on which the vegetation is bulky reflects a larger amount of visible part of the spectrum, and a smaller part of the infrared. The values of the calculated NDVI index for the given pixel of the recorded surface are in the range of -1 to +1 (Przyborski, 2017). This practically means that if there is no green leaf (green plants) on the recorded surface then the value of this index will be approximate to zero. Zero for index values indicates that there is no vegetation, while values close to $+1(0.8-0.9)$ indicate the highest possible representation of green leaf in plants. In order to reduce possible impacts on the value of the NDVI index generated by various natural factors (soil color, better leaves, water content in plants, biomass quantity, ...), it is possible to calibrate this index with several different factors. Some of the indexes are Soil Adjusted Vegetation Index, EVI (Enhanced Vegetation Index) and others (Oljaca et. al., 2016). Based on this calibration, it is possible to analyze substantially more different vegetation-biophysical parameters using the data collected by drone remote shooting. For this reason, it is increasingly common practice to correct the NDVI index to a number of factors which significantly raises the accuracy and reliability of NDVI index. As one of the correction factors, we can use the NNR (Nutrogen Nitrogen Index), which requires knowledge of the actual and critical oxygen concentration in plants, or the RI index (Response Index), in which NDVIrs calibration tape of the culture fed by the dose according to the recommendation of the basic chemical soil analysis, etc.

As mentioned earlier, drones can also be used to assess the needs for irrigation or drainage of the terrain (Mazur, 2016). In order to perform this task, drones should be equipped with hyper spectral, multispectral or thermal sensors. With the use of these sensors, parts of the terrain that are dry and require irrigation can be identify. Also, these 
sensors can monitor the plant health as well the amount of energy or heat the plant emits. From the data on the amount of heat, information about the amount of water that the plant can surrender with transpiration can be obtained. This kind of information is another indicator of the state of the plant's health. On the basis of the obtained images, it is also possible to determine the degree of damage to plants caused by the defoliation of the leaf mass due to the lack of water, which can further cause the decrease in yield (Erickson, 2004). Different researches show that the degree of loss of leaf mass at an early stage of vegetation can be determined with an accuracy between $48 \%$ and $100 \%$, while at the end of the vegetation period it can be determined with an accuracy between $81 \%$ and $100 \%$. In the reproductive stage, the degree of leaf mass loss that may cause poor insemination and yield reduction can be determined with an accuracy between $71 \%$ and $98 \%$, as demonstrated by the experimental researches described in (Erickson, 2004). Drones can also be used for the purpose of classifying plants on the production areas being observed. From the created plants classification based on recorded images, information about the cultures that are involved in the observed surface can be obtained, as well as information whether on concrete surfaces there are cereals or the surfaces are under fruit or vegetable crops (Rao et. al., 2007). In this way, the information received can greatly help with the realization of various projects where the importance of culture on the production surface is of great importance. At the same time, data can be obtained much faster, and in that way time of project realization can be accelerated. In the process of weed communities, monitoring and the mapping of the weed population on certain production area can be created based on obtained recordings. On the basis of this information, the protection of cultivated plants can be done much more efficiently, as only the areas where the weed presence is above the permissible limit will be treated. In the same time the herbicides intended for controlling the weed families detected on the production area will be used (Gutierrez et.al., 2008). In addition to efficient protection, in this way significant economic savings as well as environmental protection can be achieved, since the treatment of areas where there are no weeds will not be done. Such monitoring may be particularly important when it comes to monitoring the occurrence of weeds belonging to a group of allergens that are hazardous to human health. The meta data obtained from each of the images can identify the sites where the populations of such plants appear, with the aim of proper treatment and destruction. Locating and monitoring forests and fires on agricultural land is another task where drones are successfully applied (Hinkley $\&$ Zajkowski, 2011). Based on the recordings and metadata from them, information of the locations where the fire occurred, as well as the direction of the fire spreading and the intensity of the same can be obtained. Also, in the case of a large number of locations where fires are spotted, information about their distance, and the characteristics of the terrain affected by the fire can be provided. These information are mostly useful for fire services and people from the mountain rescue service.

\section{Legal regulations for the use of drones}

Aviation regulations can be one of the limiting factors in the use of all types of drones both in agriculture and in other areas. In many cases, the law on aviation regulations introduces different types of limitations. For example, an unmanned aircraft must not come 
out of the visibility line of the person operating it, which in many ways reduces the flight path (Lewis, 2007). From another side in many countries these regulations are not too strict. For example, during a certain time period Germany did not require any license to operate these aircrafts if their total mass does not exceed $5 \mathrm{~kg}$, and if the flight distance is not more than $1.5 \mathrm{~km}$ outside the populated place or place of departure (Aber et.al., 2010). In 2017 a new Drone Regulation came into force in Germany. Based on these regulations multicopters can only fly up to a height of $100 \mathrm{~m}$ above ground. It is allowed to operate higher if remote pilot operate on an approved model airfield or have obtained a permit from the responsible civil aviation authority. If the aircraft is in controlled airspace, there is a maximum ascent height of 50 meters. In principle, flights outside the line of visibility are allowed as long as pilot do not let drone rise higher than 30 meters above ground. If the copter weighs more than 250 grams, pilot will also need another person who can observe the copter with the naked eyes and alert him to possible dangers during the flight. Under these conditions, the law does not rate maneuver as a "flight out of sight". If these restrictions are not enough pilot can request a permit for out-of-sight flights with the National Aviation Authority. However, this approval is only granted to unmanned aerial vehicles with a take-off mass of more than 5 kilograms. For each drone owner is obligated to buy drone insurance for operations in Germany. A safety distance of 1.5 kilometers must be observed to the outer borders of airports. This rule applies to all types of drones (Markert, 2018). The latest drone regulation defines some places that drone operators have to keep 100 meters apart. These include: crowds (group of more than 12 persons), disasters, disaster areas, locations of authorities and organizations with security responsibilities, federal highways, federal waterways, railways, industrial plants, prisons and facilities of the penal system, bundeswehr installations and troops as well as other military facilities and organizations, power generation and distribution plants (power plants, wind turbines, substations, etc.), facilities in which activities requiring protection level 4 by the Biological Agents Ordinance (institutes in Hamburg, Berlin, Marburg and on the island of Riems) are carried out, lands of constitutional organs of the Federation and the federal states as well as upper and highest federal and state authorities, diplomatic and consular representations (embassies), international organizations in the sense of international law (UN, EU, NATO, etc.), and land of police and other security agencies. This already limits many maneuvers. Even in rural areas, there can be significant limitations. The Civil Aviation Authority (CAA) can grant permits to fly in these areas. Unfortunately, every federal state has his CAA. Each CAA handles the permits differently. It depends on flight location if drone pilot can get permission to fly in the areas mentioned above. With the new drone regulation from 2017, the previous separation for a drone flight is mostly canceled, and now the same rules apply to leisure pilots and commercial users. That's a positive thing because professional users have been significantly disadvantaged so far (Markert, 2018).

In United States it is required that every person who operates with the aircraft owns a pilot license to operate with a specific category of unmanned aircraft. In the United States, the flight of unmanned aircraft is strictly regulated by the Federal Aviation Administration (FAA). Because the potential loss of life from inflight accidents is unacceptably high, the FAA is understandably unwilling to loosen unmanned aircraft regulations simply to facilitate environmental remote sensing. Nearly all environmental research using unmanned aircraft within the U.S. National Airspace System is conducted within the bounds set by a Certificate of Authorization (COA) granted to a cooperating government agency. The difficulty of obtaining a COA and the cost of operating under its provisions should be considered in every prospective project. While a COA is customized for each specific operation, the following requirements may be required (FAA, 2016). 
- Even if s/he does not actually control the aircraft movement moment-bymoment, a licensed private pilot may be required to serve as the in-flight commander for the vehicle.

- Because small-scale aircraft are hard to see from a distance, provisions for detecting and avoiding other aircraft in the flying area are essential. This may include having on-ground crew members serving as horizon-to-horizon lookouts.

- A maximum altitude limit may be defined to further lower the probability of in-flight collision with commercial or private aircraft.

- The proposed unmanned aircraft operations may only be permitted within limited geographic areas sequestered from civilian aircraft operation. Unmanned aircraft flight over inhabited areas or near airports may be completely forbidden.

- $\quad$ Even if the small-scale aircraft is capable of remote flight, the aircraft may nonetheless be required to stay within unaided visual range of the flight team members. The use of a chase vehicle to maintain visual range would likely be acceptable.

- While the aircraft may be capable of autonomous flight, failsafe provisions may be required for instantly reassuming manual control in case of emergencies.

- $\quad$ Provisions may be required for the pilot of the unmanned aircraft to maintain contact with local air traffic controllers.

The cost of these regulations, as well as the process of obtaining a COA, will probably discourage many environmental researchers from adopting or developing unmanned aircrafts.

In Canada, the operation of unmanned aircrafts falls under the Canadian Aviation Regulations, which are administered by Transport Canada - the federal agency overseeing Canada's transportation systems. In order to carry out non-recreational remote sensing surveys with small unmanned aircrafts, an individual must hold insurance and a Special Fight Operations Certificate (SFOC) (Transport Canada 2008). Similarly to the United States, Canada also requires special approval that can be obtained from the air traffic control in charge of the part of the airspace in which the flight is performed. Also, in addition to take-off permition for a particular flight, a person operating a unmanned aircraft must pass a specific type of training. Within the scope of the license for the unmanned aircraft use, the insurance coverage covering the cases of falling of the aircraft which can lead to the injury of people, animals and material damage to the objects is obligatory (Hardin \& Jensen, 2011). One important restriction that impacts remote sensing with small unmanned aircrafts is the regulatory requirement that they are operated within visual range at all times, even though the telemetry between the unmanned aircrafts and ground control system may reach well beyond this limit. In practice, this means that unmanned aircrafts must remain relatively close to the takeoff point, limiting the area that can be surveyed in a single flight. The maximum distance will vary according to the size, shape and colour of the unmanned aircraft, as well as the weather conditions and lighting. Although Transport Canada may specify otherwise, for many unmanned aircrafts the maximum visual range is $<1 \mathrm{~km}$, which yields a maximum surveyable area of $\approx 3$ $\mathrm{km}^{2}$ from one location. When the flight altitude is in question, Canada has a maximum allowed flight height of $120 \mathrm{~m}$, although according to the technical characteristics of most unmanned aircraft, the minimum flight height at which the smallest turbulence effect is $640 \mathrm{~m}$. This allows for very high ground resolutions in the imagery, but makes 
it necessary to collect many more images than would otherwise be necessary, which can in turn introduce problems at the processing stage. At low flying heights, the effects of relief displacement and tree lean are often greatly exaggerated, making it extremely difficult to produce good orthoimages for some areas. In areas of high relief, the $120 \mathrm{~m}$ limitation may not be practical, and may thus rule out the use of a unmanned aircraft. Under such circumstances, Transport Canada may allow a higher flying height; however the additional time involved in obtaining the certification may impact the viability of a project. The simplified SFOC application process currently limits unmanned aircraft operation in Canada to daylight use only. For photogrammetric and most remote sensing applications this is not a problem. However the daytime-only requirement can be a limitation for thermal surveying. This particularly affects applications such as search and rescue operations, and heat loss and energy efficiency audits as night enhances thermal contrasts. With the development of reliable sense and avoid systems, night flights may become more commonplace in the future. However at present night time operation is only permitted when a full SFOC application has been lodged.

Due to safety considerations, there are also restrictions on where small unmanned aircraft surveys can be carried out. Currently in Canada, no unmanned aircraft overflights are allowed in urban areas, or within $30 \mathrm{~m}$ of people or inhabited structures unless consented. The high spatial resolution that can be obtained from small unmanned aircraft surveys would be very useful in many urban settings; however, for public safety and perhaps privacy concerns, this restriction is likely to remain in place for research and commercial applications. Further restrictions on location apply in restricted airspace, and close to airports. A recent report by the Canadian unmanned aircraft systems program design working group proposes major changes for regulation of lightweight unmanned aircrafts under $25 \mathrm{~kg}$ in weight (Transport Canada, 2012). In particular, this report proposes that unmanned aircrafts classified as "low energy" should be exempted from SFOC regulations. The proposed definition of low energy is that the kinetic energy imparted by the platform to a stationary person or object in the event of a crash is less than $12 \mathrm{~J} / \mathrm{cm} 2$, which is not considered to be a dangerous impact. The implications of this change are that many small unmanned aircrafts could potentially be operated without restriction, particularly those optimised for surveillance. This recommendation has been criticised for ignoring privacy concerns, and has prompted calls for a wider public debate on the implications of regulatory change (Gersher, 2014).

In the Republic of Serbia, in accordance with Article 8 of the Convention on International Civil Aviation (Chicago Convention), no aircraft that can be operated without a pilot must not overwhelm the territory of the Republic of Serbia without special approval or contrary to the terms stated in that approval. By legal regulations model aircraft is unmanned aircraft of operating mass of up to $20 \mathrm{~kg}$, not counting fuel for a flight, used for sports or recreational purposes, to which the provisions of the Convention on International Civil Aviation are not applicable. Unmanned aircrafts can be used for economic, scientific, educational, sporting and other purposes so as not to endanger the safety of air traffic (Cizmarov, 2015). For any damage resulting from the use of unmanned aircraft, a person using an unmanned aircraft is responsible. Article 1 of the Rules on Unmanned Aircraft defines that without any permition on the territory of the Republic of Serbia, only aircrafts with an operating mass less than $0.5 \mathrm{~kg}$ can fly, if their speed does not exceed $20 \mathrm{~m} / \mathrm{s}$ and which reaches a maximum of $15 \mathrm{~m}$ of the flight length and maximal height up to $10 \mathrm{~m}$. All other unmanned aircraft are divided into four categories according to technical characteristics. For each of the categories, a set of approvals and licenses that person which operates with aircraft mast have is defined. The maximum permissible height of the unmanned aircraft in this case is $100 \mathrm{~m}$ above the 
ground. The maximum permissible horizontal distance of the unmanned aircraft from the person handling the unmanned aircraft is $500 \mathrm{~m}$. In the same time the unmanned aircrafts that are prohibited for use are those unmanned aircrafts whose operating mass is more than $150 \mathrm{~kg}$, as well as unmanned aircraft whose flight is fully controlled by a computer installed on the aircraft. All flights need to be in line-of-sight, which is an operation of an unmanned aircraft where a remote pilot has continuous visual contact with an unmanned aircraft without using any external optical or electronic aids, where vision correction aids (such as glasses or contact lenses) are not considered as external aids.

This is the same regulation as in other mentioned countries. Article 12 of the Rules defines that a person operating an unmanned aircraft used for commercial purposes, as well as a person who manages a drone category 2, 3 and 4 can only be a health-capable adult, who has passed a knowledge test in the subject of an aviation regulations (Cizmarov, 2015). In the Article 15 of the rules on Unmanned Aircrafts is defined that the pilot of the unmanned aircraft when operating with unmanned aircraft must have manufacturer's manual for using unmanned aircraft, original or certified copy of the approval of the Directorate, act on acceptance of the declaration of competence, and certificate of achievement for successful knowledge testing. In order to maintain the correct record of unmanned aircraft in the territory of the Republic of Serbia, all unmanned aircraft used for commercial purposes, as well as drones of category 2, 3 and 4 used for non-commercial purposes, shall be entered in the Aircraft Records. For each flight operator need to submit application for allocation of airspace to the Civil-Military Coordination Unit. The application need to be submitted five working days before the planned piloting the unmanned aircraft. In case of special purpose flights in the part of airspace allocated for flying the unmanned aircraft, at the request of the Ministry of Defence or the Ministry of Interior civil-military co-ordination unit cancels the decision on the allocation of airspace and promptly notify unmanned aircraft operator and the person handling unmanned aircraft. Based on the mentioned regulations in Republic of Serbia in the class D od airspace it is prohibited to fly unmanned aircraft at a height less than $5 \mathrm{~km}$ from the reference point, unless otherwise authorized. At a distance of more than $5 \mathrm{~km}$ from the aerodrome reference point located in Class D of airspace and up to the limit of Class D of airspace, the piloting the unmanned aircraft is permitted at the height of up to $30 \mathrm{~m}$ above the ground. When the external load is in question unmanned aircraft are prohibited to carry people, animals, and dangerous goods.

In some cases unless is otherwise authorized, unmanned aircraft are prohibited: carriage of liquids, droping of items and carriage of external load that is not an element of structure and equipment. When the significant infrastructure and other facilities (power plants, electrical high voltage installations, state institutions, military facilities, water treatment plants, highways, correctional facilities, etc.) is in question, unless there is approval from the owner or user of the facility, the use of unmanned aircraft is prohibited at a horizontal distance of less than $500 \mathrm{~m}$.

\section{Economic aspects of the use of drones}

From the economic side, standard drones for public use range from 450 euros to 1,300 euros. In the domain of agriculture, the price of small drones without specific technology ranges from 1,500 euros to 3,000 euros. On the other hand, drones equipped with high-tech equipment that can simultaneously raise equipment of higher weight can reach the price above 25,000 euros. In the table bellow different drones that can be found 
on the market are compared. Selected drones are compared based on prace and based on the category in which they belong. The price of the drones was taken by the drones in the basic equipment package. This practically means that the price can only be higher if more specific equipment is added, especially when it comes to specific high-resolution sensors and cameras.

If we compare prices of drones presented in Table 1 we can see that drones with fixed wings have a higher price compared to multirotor drones. The difference in price is far from negligible, since it is a price that is several times higher. From other side if we compare performances of these two types of drones that are most frequently used in agriculture we must agree that fixed wing drones have better possibilities. Fixed wing drones like the Sentera Phoenix 2, AgDrone by HoneyComb, PrecisionHawk Lancaster and SenseFly eBee SQ are often preferred by farmers because they can cover more area and spend more time in the air than a multi-rotor platforms like the DJI Phantom 4. Fixed wing drones often carry more payload than a multi-rotor - which means more sensors - so more information can be captured in a single flight. This can reduce the total time to collect data for a given acre. The best example is the diference in price for Phantom 4 pro with and without camera for NDVI recording, which is approximately 2000 euros. In this way user gets best of both worlds - a fully-gimbaled color camera for scouting, plus NIR photos for NDVI indexing. Photos are geo-tagged and timestamped to enable quick, streamlined field scouting and identification of problem areas. Multi-rotor drones are generally cheaper than fixed wings, starting at around 1,500-10,000 euros for a professional-grade camera drone packaged with multi-spectral cameras and software for agriculture image processing.

Table 1: Comparison of different drones prices

\begin{tabular}{|l|c|c|l|}
\hline \multicolumn{1}{|c|}{ Model name } & $\begin{array}{c}\text { Fixed Wing Agriculture } \\
\text { Drones }\end{array}$ & $\begin{array}{c}\text { Multirotor Agriculture } \\
\text { Drones }\end{array}$ & \multicolumn{1}{|c|}{ Price [euros] } \\
\hline senseFly eBee SQ & + & - & 12,000 \\
\hline PrecisionHawk Lancaster 5 & + & - & 25,000 \\
\hline AgDrone by HoneyComb & + & - & 10,000 \\
\hline Sentera Phoenix 2 & + & + & 18,000 \\
\hline Phantom 4 PRO & - & + & 1,989 \\
\hline $\begin{array}{l}\text { Phantom 4 PRO with NDVI } \\
\text { Upgrade }\end{array}$ & - & + & 3,989 \\
\hline $\begin{array}{l}\text { DJI Smarter Farming } \\
\text { Package }\end{array}$ & - & + & 8,300 \\
\hline AGCO Solo & - & + & 7,850 \\
\hline Sentera Omni & - & + & 16,995 \\
\hline
\end{tabular}

If we observe sensor equipment there are many choices of imaging sensors available today for agriculture drones (Nixon, 2018). All these sensors and specific cameras can be observed like additionl equipment, which will increase the price. Options range from 200 euros for a GoPro HD camera to well over 50,000 euros for a hyper-spectral camera. The most common and cheapest type of sensor is a high-resolution camera, which takes visible wavelength images. Several of these cameras can also take near-infrared images when equipped with the right filters. Another additional charge that should certainly be counted in the total cost of using the drones is also mandatory insurance. In the Republic of Serbia 
insurance for DJI Phantom 4 Pro is approximately 200 euros per year. The problem with drone insurance is that user need to pay fixed amount regardless of the categorie to which the dron belongs. More precisely, all the drones are categorized as drones for commercial use, and based on that amount of insurance is calculated. Such insurance police covers property damage and liability for about 6000 euros. Another example shows that the costs to unsure a 20,000 euros drone aboard are approximately 2,495 euros. This amout will be paid for PrecisionHawk Lancaster (Nixon, 2018). When the use of drones is in focus we can tell that the benefits are multiples. For example Agris Co-op Ltd. in Chatham, Ontario is one of the first precision agriculture drone imaging service providers to enter the Canadian market. Using fixed-wing eBee and Swinglet drones, the firm shoots high-res NDVI images of corn fields in Ontario for a price of about 5 euros an acre. A single flyover covers 100 acres in 15 minutes, capturing about 300 images for a price of 500 euros. This compares to a cost of about 1,500-2,000 euros for satellite or manned aircraft photography of 100 acres, or 15-20 euros per acre. In the same time these older methods yield less resolution, can be hampered by cloud cover, and take more time to process the images. On a single day, Agris can cover more than 1,000 acres using a single drone. Images are post-processed in about 2 days.

\section{Conclusion}

The improvement of agricultural production in recent years is based on the use of information and communication technologies in agriculture. The possibilities offered by the use of these technologies are used both in terms of automation and modernization of agricultural machinery, as well as in the use of independent devices. Drones as one of the types of multidisciplinary devices are very useful in the field of improving agricultural production, as witnessed by a large number of surveys.

Rather than opting for one type of drone, some farmers and operators purchase less expensive versions of both. A fixed wing drone is used for large open spaces where long, unobstructed straight-line passes are possible, and, a small inexpensive multi-rotor is used for spot-checking trouble areas more closely, for quick scouting missions and for handling area a plane cannot fly over. Lots of farmers today start by buying a ready-to-fly 1,500 euros quadcopter like a Phantom 4 PRO or an NDVI-equipped pre-tested solution like DJI's Smarter Farming Package. After testing the ROI of drone surveying, they may upgrade to more expensive and more efficient multi rotor and fixed wing packages that can integrate with their Farm Management Information Systems (FMIS) and Agronomy Management Systems (AMS).

In our opinion, the regulations that control small-scale aircraft flight form the greatest obstacle to the technology's widespread adoption for environmental remote sensing. first group includes those practitioners who seek to use existing small-scale aircraft for environmental monitoring. Their primary interest is not building and testing unmanned aircraft, but applying them as tools to gather environmental data. For many of these potential non-pilot users, the hurdle of obtaining the necessary approvals to conduct their data gathering is largely insurmountable. Consequently, the civilian demand for small-scale unmanned aerial systems remains stagnant. The second stakeholding group includes those corporations developing and selling remotely piloted systems (and allied components and services) whose primary motive is profit. These corporations almost 
universally focus on potential sales within the military and federal law enforcement sector where regulation obstacles are more easily managed. Until regulatory requirements can be satisfied and the demand for environmental small-scale aircraft effectively increased, the current corporate focus will not be adjusted to serve environmental remote sensing.

\section{References}

Aber, J. S., Marzolff, I., \& Ries, J. B. (2010). Smallformat aerial photography: principles, techniques and geoscience applications. Oxford, Elsevier.

Barrientos, A., Colorado, J., Cerro, J. D., Martinez, A., Rossi, C., Sanz, D., \& Valente, J. (2011). Aerial remote sensing in agriculture: A practical approach to area coverage and path planning for fleets of mini aerial robots. Journal of Field Robotics, 28(5), 667-689.

Cizmarov, M. (2015). Pravilnik o bespilotnim vazduhoplovima. Direktorat civilnog vazduhoplovstva Republike Srbije.

DJI News (2017). DJI Raises Bar For Aerial Imaging With Two New Flying Cameras, Retrieved January 08, 2017., from: http://www.dji.com/newsroom/news/djiraises-barfor-aerial-imaging-with-two-new-flying-cameras

Erickson, B. J., Johannsen, C. J., Vorst, J. J., \& Biehl, L. L. (2004). Using remote sensing to assess stand loss and defoliation in maize. Photogrammetric Engineering \& Remote Sensing, 70(6), 717-722.

FAA, (2016). Unmanned Aircraft Systems (UAS), U.S. Department of transportation federal aviation administration. Retrieved June 20, 2018, from https://www.faa. gov/documentLibrary/media/Order/FAA_JO_7200_23_2.pdf

Gersher, S. (2014). Canada's domestic regulatory framework for RPAS. A call for public deliberation. Journal of Unmanned Vehicle Systems, 2(1), 1-4.

Gutierrez, P. A., Lopez-Granados, F., PenaBarragan, J. M., Jurado-Exposito, M., \& HervasMartinez, C. (2008). Logistic regression product-unit neural networks for mapping Ridolfia segetum infestations in sunflower crop using multitemporal remote sensed data. Computers and Electronics in Agriculture, 64(2), 293-306.

Hardin, P. J., \& Jensen, R.R. (2011). Small-scale unmanned aerial vehicles in environmental remote sensing: Challenges and opportunities. GIScience \& Remote Sensing, 48, 99-111.

Hinkley, E. A., \& Zajkowski, T. (2011). USDA forest service-NASA: unmanned aerial systems demonstrations-pushing the leading edge in fire mapping. Geocarto International, 26(2), 103-111.

Inside Unmanned Systems (2017). enseFly, a Parrot Company, Introduces eXom, a Rotary Drone that Features Five Vision Sensors and the Ability to Record a Variety of Imagery, Retrieved January 05, 2017., from: http://insideunmannedsystems. com/sensefly-parrotcompany-introduces-exom-rotary-drone-featuresfivevision-sensors-ability-record-variety-imagery

Lan, Y., Huang, Y., Martin, D. E., \& Hoffmann, W. C. (2009). Development of an 
airborne remote sensing system for crop pest management: System integration and verification. Transactions of the ASABE, 25, 607-615.

Livona. (2017). Economical aerial aerophotogrametry system, Retrieved December 20, 2017., from: http:/www.livona.rs/bas/ebee/

Lewis, G. (2007). Evaluating the use of a low-cost unmanned aerial vehicle platform in acquiring digital imagery for emergency response. Geomatics solutions for disaster management, Berlin Heidelberg, Springer.

Markert, F. (2018). Drone Laws in Germany, Retrieved: August 20, 2018. from https:// drone-traveller.com/drone-laws-germany/

Mazur, M. (2016). Six ways drones are revolutionizing agriculture. MIT Technology Review.

Nixon, A. (2018). Best Drones For Agriculture 2018: The Ultimate Buyer's Guide. Retrieved September 18, 2018., from: http://bestdroneforthejob.com/dronebuying-guides/agriculture-drone-buyers-guide/

Oljača, M., et. al (2016). Application of drones in agriculture. In Proceedings of the 18th Scientific Conference with International Participation - Current Problem of Agriculture Mechanization (pp. 89-101). Beograd.

Parrot (2017), Drones for agriculture: Drones in the crop scouting workflow, Retrieved April 15, 2017., from: https://www.sensefly.com/applications/agriculture.html

Pcfoto (2016), Lansirani novi dronovi - DJI Phantom 4 Pro i DJI Inspire 2. Retrieved March 08, 2018., from: http://pcfoto.biz/vest-412795-lansirani-novi-dronovidjiphantom-4-pro-i-dji-inspire-2

Precision Hawk. (2014). Drones to Elevate Business Intelligence, Retrieved December 20, 2017., from: http://www.precisionhawk.com/lancaster

Przyborski, P. (2017). Measuting Vegetation (NDVI \& EVI), Earth Observatory, Retrieved: June 01,2017., from: http://earthobservatory.nasa.gov/Features/ MeasuringVegetation/measuring_vegetation_2.php

Rao, R., Garg, P. K., \& Ghosh, S. K. (2007). Development of an agricultural crops spectral library and classification of crops at cultivar level using hyperspectral data. Precision Agriculture, 8(4-5), 173-185.

Robertson, M., Carberry, P., \& Brennan, L. (2007). The economic benefits of precision agriculture: case studies from Australian grain farms. Grains Research \& Development Corporation.

Solo AGCO Edition (2017). Agriculture from a new perspective, Retrived January 05, 2017. from: http://www.pages05.net/agco/SOLO_UAV/

Srinivasan, A. (2006). Handbook of precision agriculture: Principles and applications. Danvers, MA:CRC Press.

Transport Canada. (2012). UAV systems program design working group phase 1 final report. Retrieved August 20, 2018, from http://www.h-a-c.ca/UAV_REPORT.pdf.

Trimble (2017). Trimble UX5 Aerial Imaging Solution for Agriculture, Retrieved January 05, 2018., from:http://uas.trimble.com/ux5

Zhang, C., \& Kovacs, J. M. (2012). The application of small unmanned aerial systems for precision agriculture: a review. Precision agriculture, 13(6), 693-712. 